\title{
Mechanisms for the Intermetallic Formation during the Sn-20ln-2.8Ag/Ni Soldering Reactions
}

\author{
T.H. CHUANG, ${ }^{1,2}$ K.W. HUANG, ${ }^{1}$ and W.H. LIN $^{1}$ \\ 1.--Institute of Materials Science and Engineering, National Taiwan University, Taipei 106, \\ Taiwan. 2._E-mail: tunghan@ccms.ntu.edu.tw
}

The morphology and growth kinetics of intermetallic compounds formed during the interfacial reactions between liquid Sn-20In-2.8Ag solder and $\mathrm{Ni}$ substrates are investigated. Energy-dispersive x-ray (EDX) analysis identifies the composition of the interfacial intermetallics as $\mathrm{Ni}_{3}\left(\mathrm{In}_{0.99} \mathrm{In}_{0.01}\right)_{4}$. The soldering reactions at lower temperatures $\left(225-275^{\circ} \mathrm{C}\right)$ result in the predominant formation of a homogeneous intermetallic layer whose growth is diffusion controlled. At higher soldering temperatures $\left(300-350^{\circ} \mathrm{C}\right)$, the interfacial intermetallics appear to be long needlelike crystals, and the grooves in between the intermetallics provide fast-diffusion paths for $\mathrm{Ni}$ atoms to react with Sn atoms at the intermetallic front, which leads to interface-controlled growth kinetics. The intermetallic needles turned out to be flat slablike after selective etching of the unreacted solder. Kinetics analysis showed that they not only lengthened in the longitudinal direction, but also coarsened transversely by the Ostwald ripening mechanism.

Key words: Sn-20In-2.8Ag, Ni substrate, intermetallic slabs, growth kinetics, transverse ripening

\section{INTRODUCTION}

The development of $\mathrm{Pb}$-free solders is needed in the electronics industry due to environmental concerns. Among an array of promising candidates, Sn-3.5Ag solder possesses the advantages of high strength, good ductility, long thermal fatigue life, improved creep resistance, and low cost. ${ }^{1-3}$ However, the high melting point of this alloy $\left(221^{\circ} \mathrm{C}\right)$ as compared to the traditional $\mathrm{Sn}-37 \mathrm{~Pb}$ solders $\left(183^{\circ} \mathrm{C}\right)$ is an issue in electronic packaging. On the other hand, there is Sn-51In, a typical low-melting-point solder $\left(118^{\circ} \mathrm{C}\right)$. In application, it can also boast such merits as high ductility, improved fatigue resistance, and good wettability. ${ }^{4,5}$ Furthermore, an In-containing solder has been found to form an $\mathrm{Au}$ dissolution barrier $\mathrm{AuIn}_{2}$ at the solder/pad interface, which can prevent the formation of brittle intermetallic compounds such as $\mathrm{AuSn}_{4}$ in the solder matrix. ${ }^{6}$ Unfortunately, the cost of the In content within these solders is notably high, thereby limiting their applications to those cases

(Received October 30, 2003; accepted January 6, 2004) where production costs are of a lesser concern. A compromise may be reached by consolidating the features of Sn-3.5Ag and Sn-51In alloys, which gives rise to the development of the Sn-20In-2.8Ag solder.

Soldering is a low-temperature joining process widely employed for electronic packaging. Moreover, this technique is also used to bond recycled sputtering targets with their backing plates. During the soldering reaction process, the formation of intermetallic compounds at the interfaces is a sign of a sound joint. However, an overgrowth of such intermetallics will cause cracking along the interfaces. Nickel is one of the most popular substrate materials for soldering, so the solid/liquid reactions of $\mathrm{Ni}$ with certain commonly used solders (such as pure $\mathrm{Sn},{ }^{7-9}$ pure In, ${ }^{10} \mathrm{Sn}-51 \mathrm{In},{ }^{11,12} \mathrm{Sn}-58 \mathrm{Bi},{ }^{8} \mathrm{Sn}-9 \mathrm{Zn},{ }^{13}$ and $\mathrm{Sn}-37 \mathrm{~Pb}^{14}$ alloys) have been investigated. In this present study, the interfacial reactions between liquid $\mathrm{Sn}-20 \mathrm{In}-2.8 \mathrm{Ag}$ solder and $\mathrm{Ni}$ substrates take place at temperatures ranging from $225^{\circ} \mathrm{C}$ to $350^{\circ} \mathrm{C}$ for 15-90 min, with the aim that the mechanism of soldering reactions for this newly developed solder alloy be clarified. 


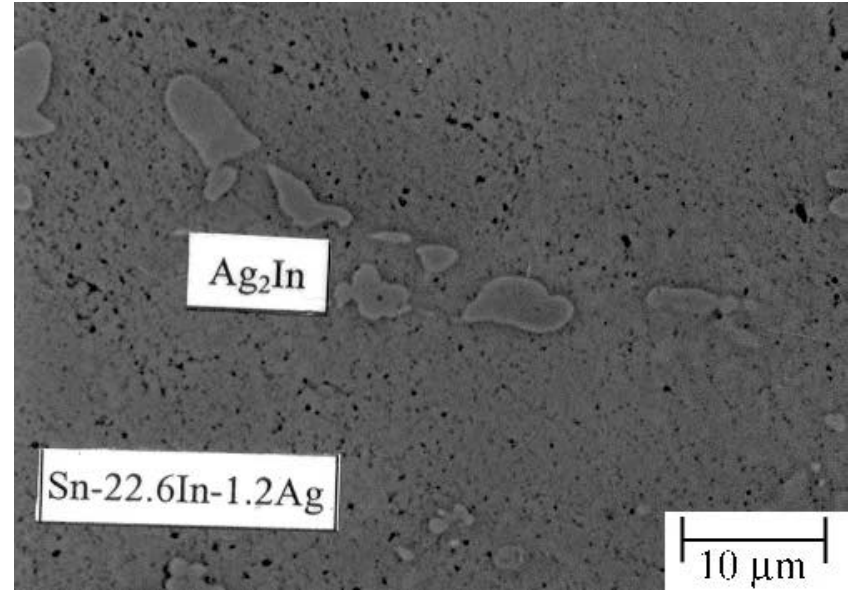

Fig. 1. Microstructure of the as-cast $\mathrm{Sn}-20 \mathrm{ln}-2.8 \mathrm{Ag}$ solder containing coarse $\mathrm{Ag}_{2} \mathrm{In}$ intermetallic islands in the $\mathrm{Sn}-22.6 \mathrm{ln}-1.2 \mathrm{Ag}$ matrix.
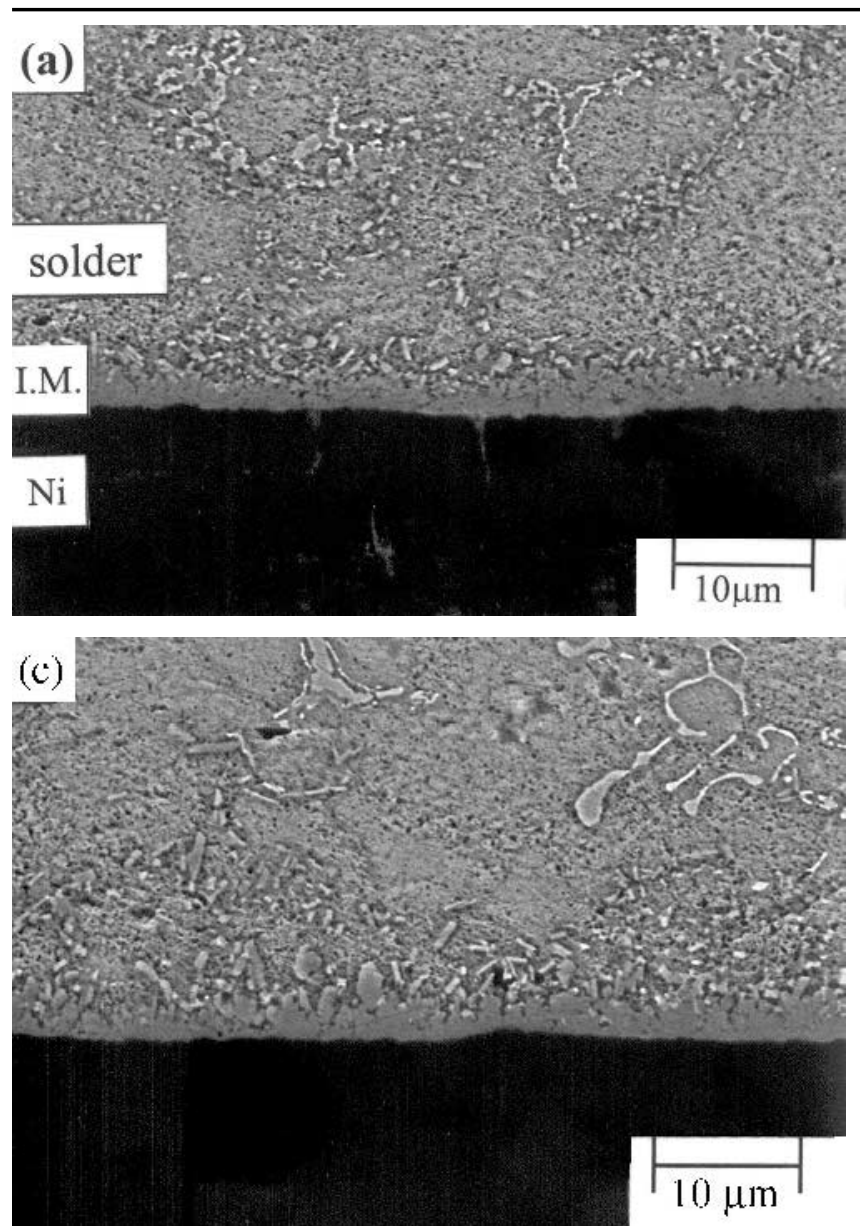

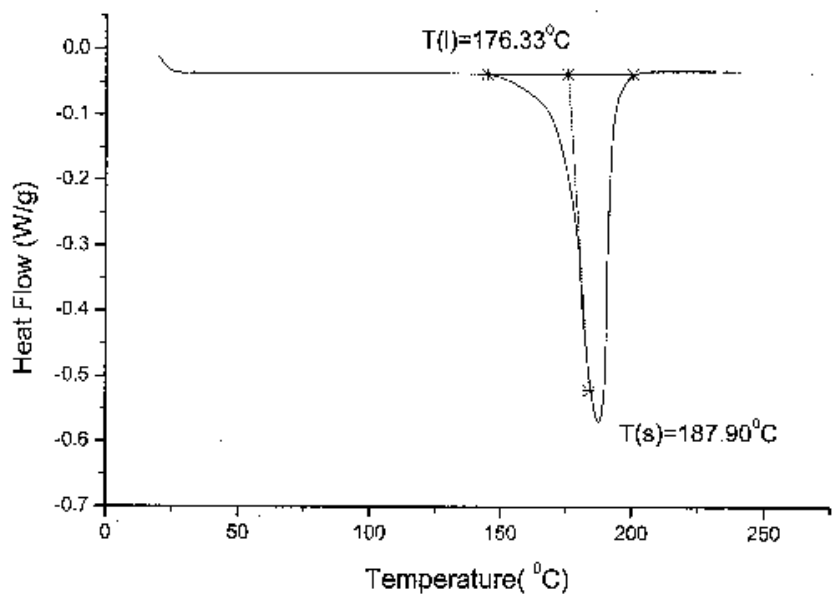

Fig. 2. DSC analysis of the Sn-20ln-2.8Ag solder gives solidus/ liquidus at $176.33^{\circ} \mathrm{C}$ and $187.90^{\circ} \mathrm{C}$, respectively.
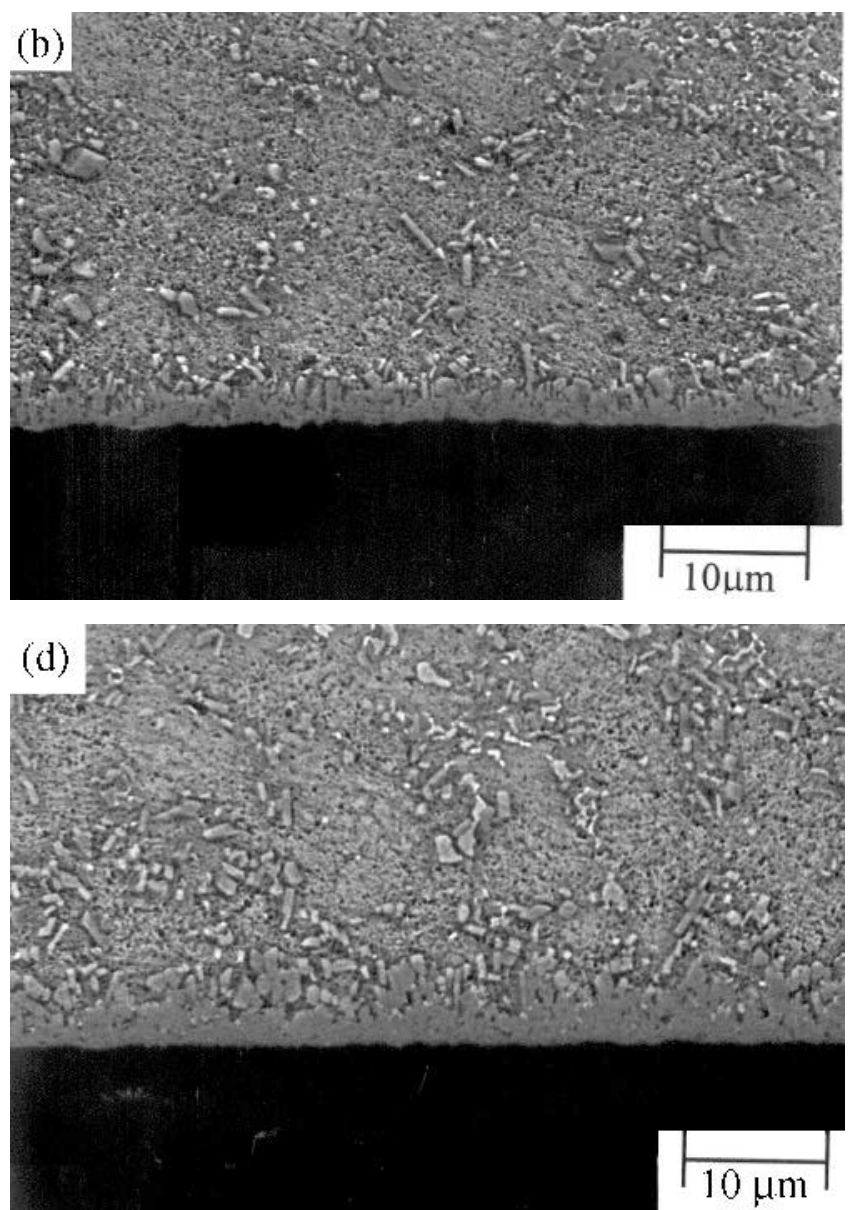

Fig. 3. Morphology of the intermetallic compounds formed during the interfacial reactions between Sn-20ln-2.8Ag solder and Ni substrates at $225^{\circ} \mathrm{C}$ for (a) $30 \mathrm{~min}$, (b) $45 \mathrm{~min}$, (c) $60 \mathrm{~min}$, and (d) $90 \mathrm{~min}$.

\section{EXPERIMENTAL}

The Sn-20In-2.8Ag (wt.\%) solder was prepared by vacuum melting $\left(10^{-5}\right.$ torr $)$ at $600^{\circ} \mathrm{C}$. The ingot was homogenized for $120 \mathrm{~h}$ at $100^{\circ} \mathrm{C}$ and then rolled into a $0.2-\mathrm{mm}$-thick foil. The melting temperature of this $\mathrm{Sn}-20 \mathrm{In}-2.8 \mathrm{Ag}$ solder was taken at a heating rate of $10 \mathrm{~K} / \mathrm{min}$ by means of differential scanning calorimetry (DSC). The Ni substrates with dimensions $8 \mathrm{~mm} \times 12 \mathrm{~mm}$ were cut from a 1 -mm-thick Ni plate (99.5\% purity), ground with $\mathrm{SiC}$ paper and polished with $1 \mu \mathrm{m}$ and $0.3 \mu \mathrm{m} \mathrm{Al}_{2} \mathrm{O}_{3}$ powders. Soldering reactions were carried out in an infrared furnace under a vacuum of $10^{-3}$ torr. The heating processes were done at various temperatures from $225^{\circ} \mathrm{C}$ to $350^{\circ} \mathrm{C}$ for $15-90 \mathrm{~min}$. The specimens could 

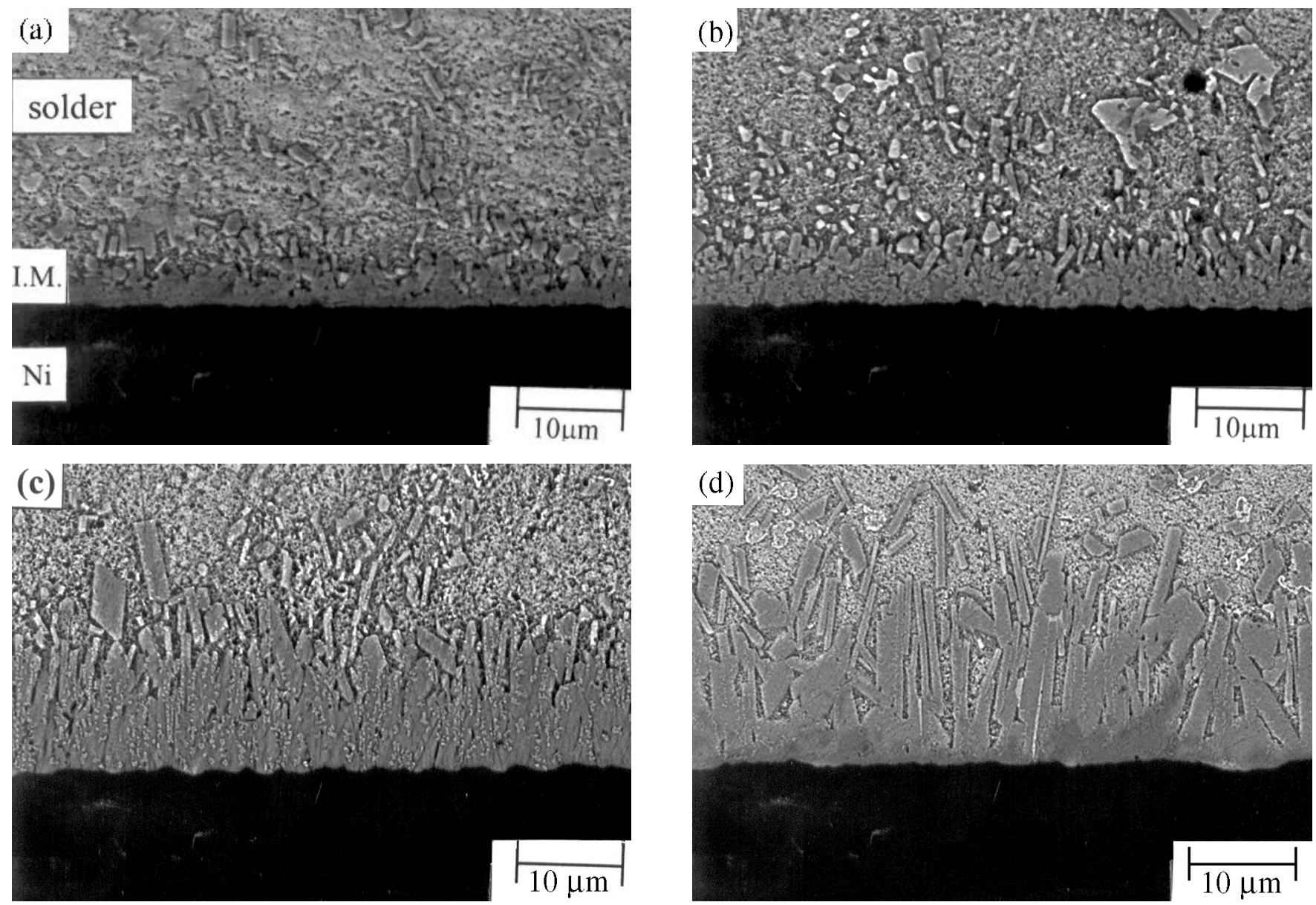

Fig. 4. Morphology of the intermetallic compounds formed during the interfacial reactions between Sn-20ln-2.8Ag solder and Ni substrates at $350^{\circ} \mathrm{C}$ for various times: (a) $15 \mathrm{~min}$, (b) $30 \mathrm{~min}$, (c) $45 \mathrm{~min}$, and (d) $90 \mathrm{~min}$.

be cooled to room temperature in 2 min via a watercooling system installed within the furnace. A rosin mildly activated type flux was used to eliminate the oxide layer on the surfaces of the solder and $\mathrm{Ni}$ substrates.

For metallographic analysis, the soldered specimens were cross sectioned, ground with $\mathrm{SiC}$ paper, and polished with $1 \mu \mathrm{m}$ and $0.3 \mu \mathrm{m} \mathrm{Al}_{2} \mathrm{O}_{3}$ powders. The morphology of intermetallic compounds formed in the solder matrix and at the $\mathrm{Sn}-20 \mathrm{In}-2.8 \mathrm{Ag} / \mathrm{Cu}$ interface was observed by scanning electron microscopy. The chemical compositions of the intermetallic compounds were identified with energy-dispersive x-ray (EDX) spectroscopy. For kinetic analysis, the growth length $(\Delta \mathrm{X})$ of the intermetallics was determined by measuring the needle length at 30 equally-spaced points and calculating the average value. The standard deviation for various intermetallic compound layers was between $1.2 \mu \mathrm{m}$ and $3.5 \mu \mathrm{m}$. For further investigation of the three-dimensional morphology of the intermetallic compounds, the unreacted solder matrices of these soldered specimens were selectively etched away in an aqueous solution of $35 \% \mathrm{HF}+10 \%$ $\mathrm{HNO}_{3}+55 \% \mathrm{H}_{2} \mathrm{O}$. The thickness $(\Delta \mathrm{W})$ of the exposed intermetallic wickers after selective etching was also measured. The kinetics and mechanism of such a transverse coarsening phenomenon in intermetallics were analyzed.

\section{RESULTS AND DISCUSSION}

The microstructure of the as-cast Sn-20In-2.8Ag solder is shown in Fig. 1, which contains islandlike precipitates embedded in the Sn-rich matrix. These islandlike precipitates possess a composition (at.\%) of $\mathrm{Ag}:$ In $=67.7: 32.3$, which corresponds to the $\mathrm{Ag}_{2}$ In phase. A previous study indicated the appearance of fine $\mathrm{Ag}_{3} \mathrm{Sn}$ particles in large quantities in an as-cast $\mathrm{Sn}-3.5 \mathrm{Ag}$ solder ${ }^{15}$ but those particles are absent in this Sn-20In-2.8Ag solder. The EDX analysis also shows that the formation of $\mathrm{Ag}_{2}$ In precipitates causes the composition (wt.\%) of the matrix to deviate from $\mathrm{Sn}-20 \mathrm{In}-2.8 \mathrm{Ag}$ to $\mathrm{Sn}-22.6 \mathrm{In}-1.2 \mathrm{Ag}$. Differential scanning calorimetry analysis in Fig. 2 indicates that the solidus and liquidus temperatures of this solder are $176.33^{\circ} \mathrm{C}$ and $187.90^{\circ} \mathrm{C}$, respectively, which are quite near the eutectic point of traditional $\mathrm{Sn}-37 \mathrm{~Pb}$ solder $\left(183^{\circ} \mathrm{C}\right)$.

There are two types of intermetallic compounds formed at the $\mathrm{Sn}-20 \mathrm{In}-2.8 \mathrm{Ag} / \mathrm{Ni}$ interfaces after soldering reactions at various temperatures. As shown in Fig. 3, the interfacial intermetallic layers are relatively homogeneous at lower temperatures, 

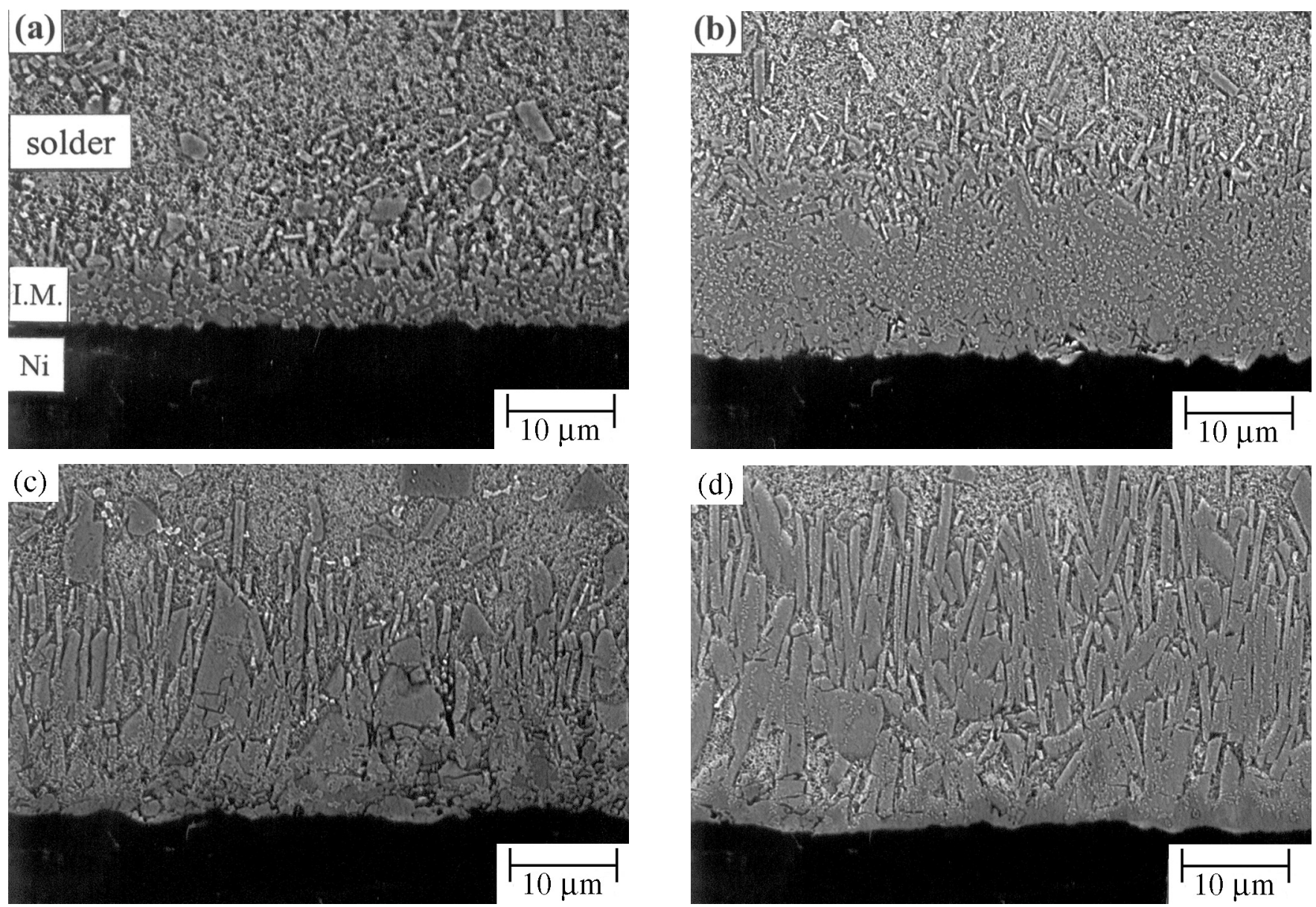

Fig. 5. Morphology of the intermetallic compounds formed during the interfacial reactions between liquid Sn-20ln-2.8Ag solder and Ni substrates for 60 min at various temperatures: (a) $250^{\circ} \mathrm{C}$, (b) $275^{\circ} \mathrm{C}$, (c) $300^{\circ} \mathrm{C}$, and (d) $325^{\circ} \mathrm{C}$.

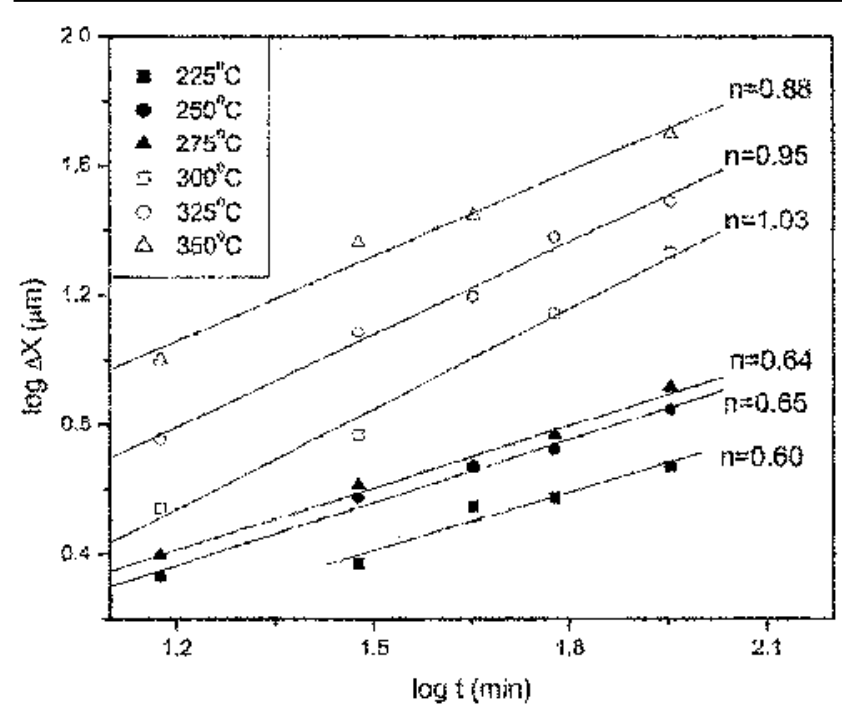

Fig. 6. Log plot for the growth length $(\Delta \mathrm{X})$ of the intermetallic compounds $\mathrm{Ni}_{3}\left(\mathrm{In}_{0.99} \mid \mathrm{n}_{0.01}\right)_{4}$ formed during the interfacial reactions between $\mathrm{Sn}-20 \mathrm{ln}-2.8 \mathrm{Ag}$ solder and $\mathrm{Ni}$ substrates as a function of reaction time $(\mathrm{t})$.

though accompanied with the presence of a certain number of elongated intermetallic grains at their reaction fronts. The presence of such elongated intermetallic compounds begins to dominate, enabling

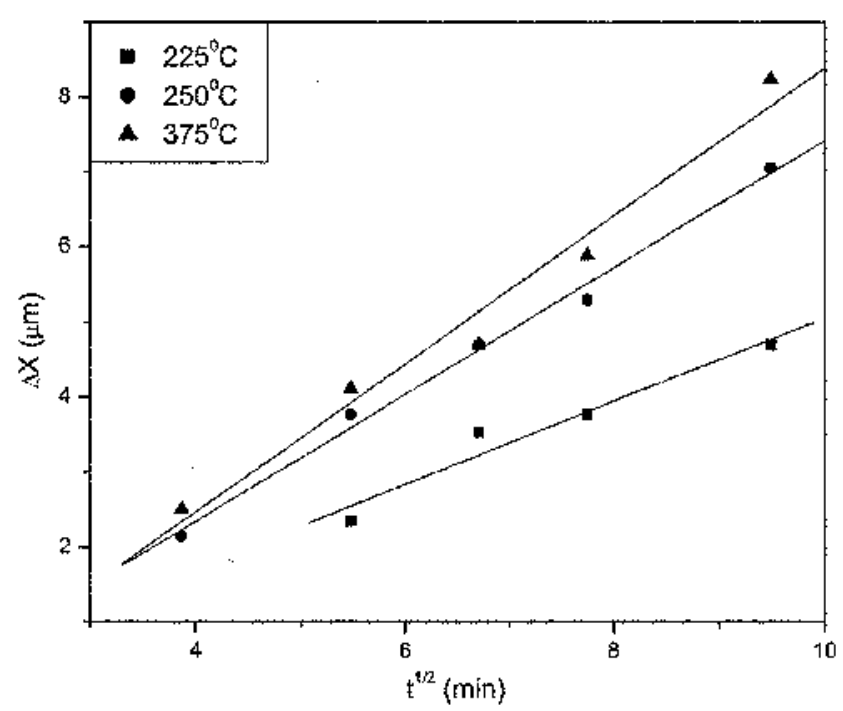

Fig. 7. Growth length $(\Delta X)$ of the intermetallic compounds $\mathrm{Ni}_{3}\left(\mathrm{In}_{0.99} \mathrm{n}_{0.01}\right)_{4}$ formed at $\mathrm{Sn}-20 \mathrm{ln}-2.8 \mathrm{Ag} / \mathrm{Ni}$ interfaces after soldering reactions at lower temperatures ranging from $225^{\circ} \mathrm{C}$ to $275^{\circ} \mathrm{C}$ versus the square root of reaction time $\left(t^{1 / 2}\right)$.

these intermetallic compounds to further evolve into long needle shapes at a higher soldering temperature, as revealed in Fig. 4. Figure 5 demonstrates more clearly the change in morphology for inter- 


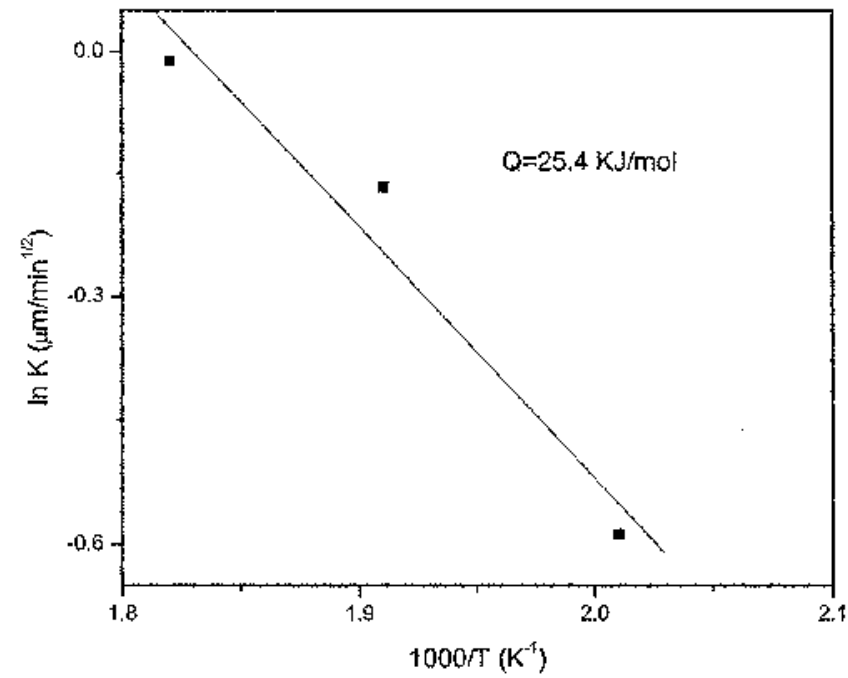

Fig. 8. Arrhenius plot of the reaction constant $(K)$ for the intermetallic growth during the interfacial reactions between liquid $\mathrm{Sn}$-20ln$2.8 \mathrm{Ag}$ solder and $\mathrm{Ni}$ substrates at lower temperatures ranging from $225^{\circ} \mathrm{C}$ to $275^{\circ} \mathrm{C}$.

metallic compounds formed in the high $\left(300^{\circ} \mathrm{C}\right.$ to $\left.350^{\circ} \mathrm{C}\right)$ and low $\left(225^{\circ} \mathrm{C}\right.$ to $\left.275^{\circ} \mathrm{C}\right)$ temperature ranges. The EDX analyses indicate that both types of intermetallics are of the same composition (at.\%):
$\mathrm{Ni}: \mathrm{Sn}: \mathrm{In}=45.0: 54.4: 0.6$, which corresponds to the $\mathrm{Ni}_{3}\left(\mathrm{Sn}_{0.99} \mathrm{In}_{0.01}\right)_{4}$ phase. Figure 6 shows the log plots of the growth length $(\Delta \mathrm{X})$ of the intermetallic compounds as a function of reaction time $(t)$. The $n$ values in the kinetic relation $\left(\Delta \mathrm{X}=\mathrm{t}^{\mathrm{n}}\right)$ are calculated from the slopes of the plots for various soldering temperatures. The results indicate that the $n$ values range from 0.60 to 0.65 with an average of 0.63 at lower temperatures $\left(225-275^{\circ} \mathrm{C}\right)$. In this temperature range, the intermetallic growth during the soldering reactions tends to be diffusion controlled. On the other hand, higher soldering temperatures $\left(300-350^{\circ} \mathrm{C}\right)$ yield quite larger $\mathrm{n}$ values ranging from 0.83 to 1.03 (average 0.91 ), which leads to the inference of an interface-controlled reaction mechanism. The discrepancy in kinetics for intermetallic growth at lower and higher temperatures can be clarified by the different morphology of intermetallic compounds formed in both temperature ranges. At the lower soldering temperatures, there is an intermetallic layer with a homogenous matrix existing in between liquid Sn-20In-2.8Ag solder and the Ni substrate. The rate-controlling step in the growth of intermetallic compounds is believed to be the diffusion of $\mathrm{Ni}$ atoms through the "dense" intermetallic layer. When the dense intermetallic layer is transformed
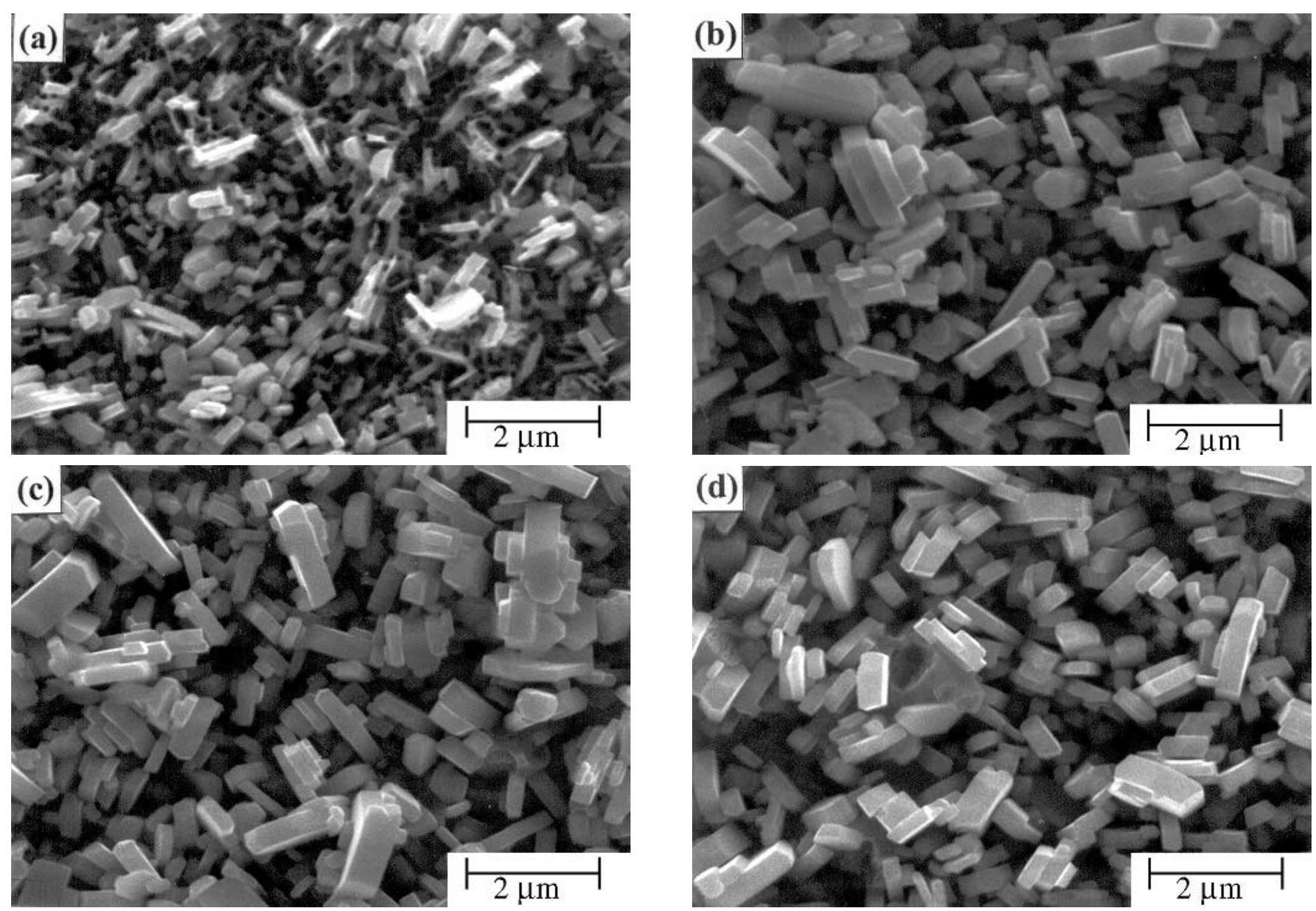

Fig. 9. Appearance of intermetallic slabs formed at the Sn-20ln-2.8Ag/Ni interfaces after selective etching away of the unreacted solder. Soldering reactions took place at $225^{\circ} \mathrm{C}$ for various times: (a) $30 \mathrm{~min}$, (b) $45 \mathrm{~min}$, (c) $60 \mathrm{~min}$, and (d) $90 \mathrm{~min}$. 

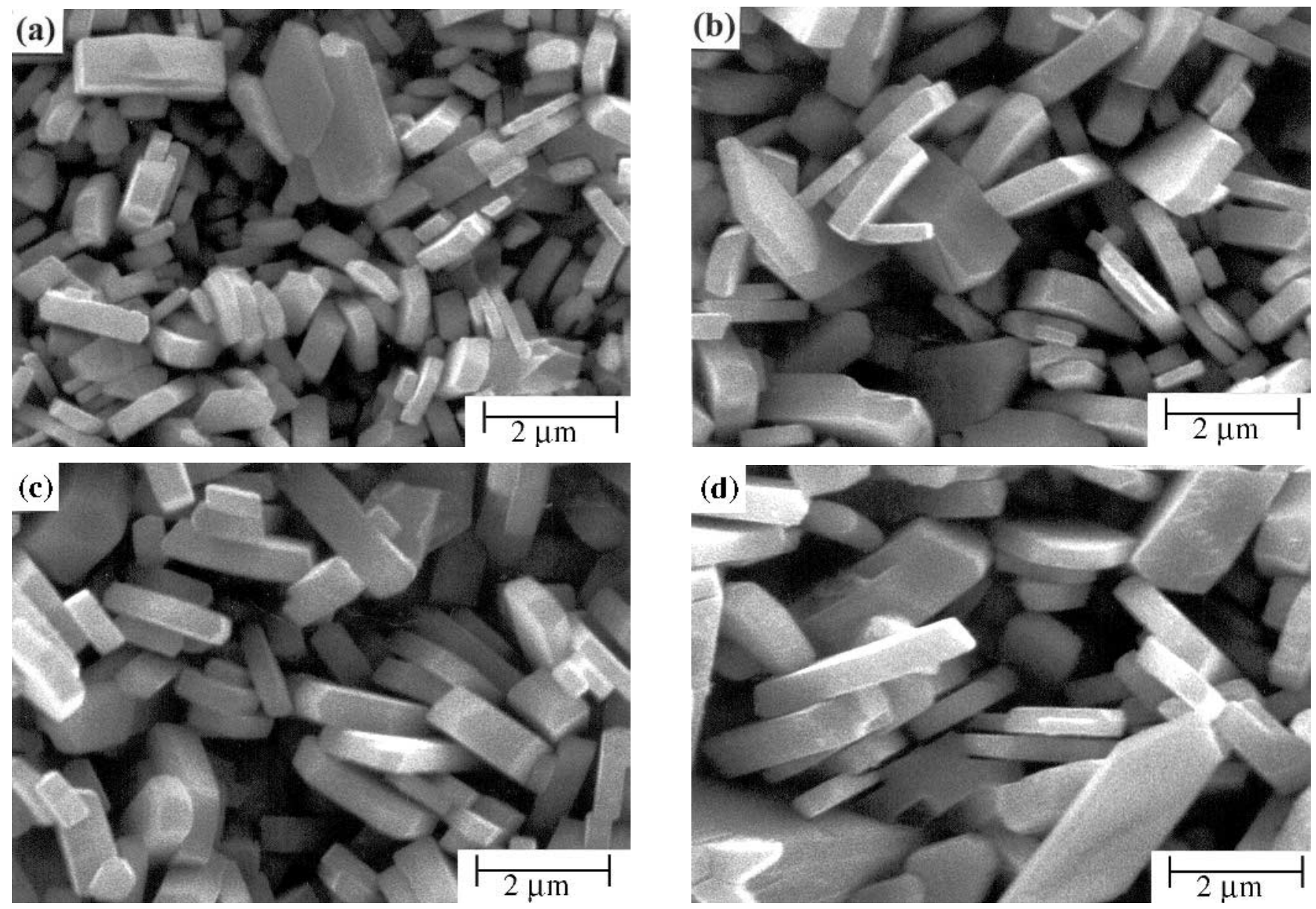

Fig. 10. Appearance of intermetallic slabs formed at the Sn-20ln-2.8Ag/Ni interfaces after selective etching away of the unreacted solder. Soldering reactions took place at $300^{\circ} \mathrm{C}$ for various times: (a) $30 \mathrm{~min}$, (b) $45 \mathrm{~min}$, (c) $60 \mathrm{~min}$, and (d) $90 \mathrm{~min}$.

into a layer of "loose" intermetallic needles with the increase of soldering temperature, as evidenced in Fig. 5 , the grooves in between the parallel-aligned intermetallic needles provide fast-diffusion paths for $\mathrm{Ni}$ atoms to react with the $\mathrm{Sn}$ atoms. A linear kinetic relation (interface controlled) to the growth of interfacial intermetallic can be inferred.

In order to further verify the diffusion-controlled mechanism for the growth of intermetallic compounds $\mathrm{Ni}_{3}\left(\mathrm{Sn}_{0.99} \mathrm{In}_{0.01}\right)_{4}$ at the $\mathrm{Sn}-20 \mathrm{In}-2.8 \mathrm{Ag} / \mathrm{Ni}$ interfaces in the temperature range between $225^{\circ} \mathrm{C}$ and $275^{\circ} \mathrm{C}$, the growth distance of intermetallics is plotted against the square root of reaction time (Fig. 7). The growth rate constant $\left(K=\Delta \mathrm{X} / \mathrm{t}^{1 / 2}\right)$ of intermetallic compounds is plotted in an Arrhenius diagram, as shown in Fig. 8. The activation energy as calculated in Fig. 8 is $25.4 \mathrm{KJ} / \mathrm{mol}$. This value is close to the activation energy for the lattice diffusion of $\mathrm{Ni}$ in $\mathrm{Sn}(18.1 \mathrm{KJ} / \mathrm{mol})$, as reported by Yeh and Huntington. ${ }^{16}$

Selective etching of the unreacted $\mathrm{Sn}-20 \mathrm{In}-2.8 \mathrm{Ag}$ solder after soldering reactions at $225^{\circ} \mathrm{C}$ leads to the exposure of elongated grains at the front of the homogeneous intermetallic layer. Figure 9 demonstrates the three-dimensional morphology of these elongated intermetallic grains shaped in the form of flat slabs. The slab shape of such intermetallic compounds becomes more pronounced for the selectively etched specimens when soldering reactions take place at higher temperature, as shown in Fig. 10. It is also shown in Figs. 10 and 11 that these intermetallic flat slabs will coarsen with reaction time and temperature. In order to clarify the mechanism for such transverse coarsening of the intermetallic slabs during the $\mathrm{Sn}-20 \mathrm{In}-2.8 \mathrm{Ag}_{(1)} / \mathrm{Ni}_{(\mathrm{s})}$ interfacial reactions, the thickness $(\Delta \mathrm{W})$ of the intermetallic slabs formed at various soldering temperatures is measured and shown in the log plots in Fig. 12. The growth rate of intermetallics in the transverse direction is much lower than that in the longitudinal direction, as shown in Fig. 6 . The $\mathrm{n}$ values in the kinetic relation $\Delta \mathrm{W}=\mathrm{t}^{\mathrm{n}}$ for transverse coarsening, as calculated from the slopes of the plots, range from 0.30 to 0.44 with an average of 0.38 , i.e., $\Delta \mathrm{W} \sim \mathrm{t}^{1 / 3}$. The results imply that the transverse coarsening of intermetallic slabs is governed by the Ostwald ripening mechanism. ${ }^{17,18}$

\section{CONCLUSIONS}

Intermetallics that have two types of morphology with the same composition $\mathrm{Ni}_{3}\left(\mathrm{Sn}_{0.99} \mathrm{In}_{0.01}\right)_{4}$ appear at the $\mathrm{Sn}-20 \mathrm{In}-2.8 \mathrm{Ag} / \mathrm{Ni}$ interface after soldering 

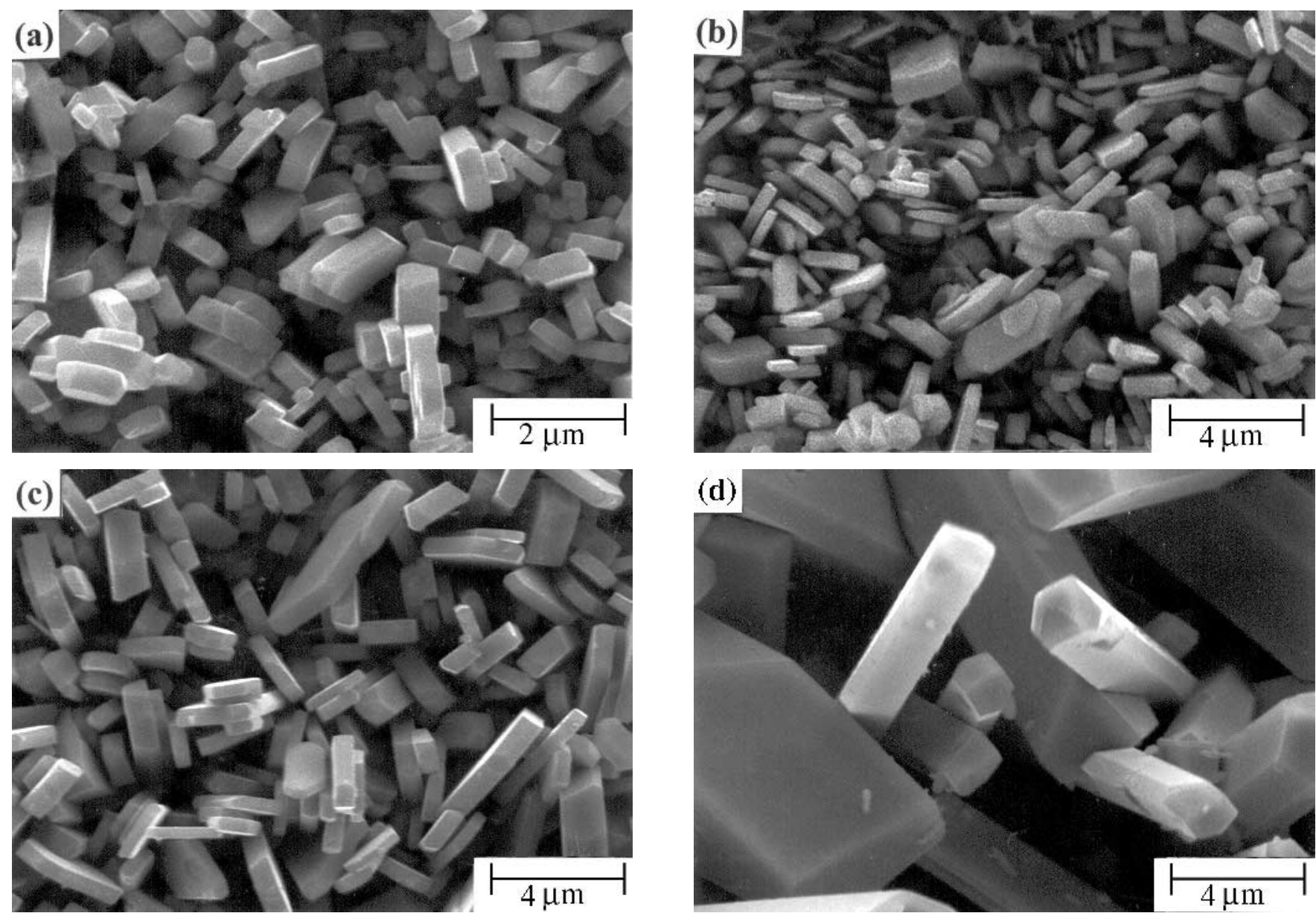

Fig. 11. Appearance of intermetallic slabs formed at the Sn-20ln-2.8Ag/Ni interfaces after selective etching away of the unreacted solder. Soldering reactions took place for 60 min at various temperatures: (a) $250^{\circ} \mathrm{C}$, (b) $275^{\circ} \mathrm{C}$, (c) $325^{\circ} \mathrm{C}$, and (d) $350^{\circ} \mathrm{C}$.

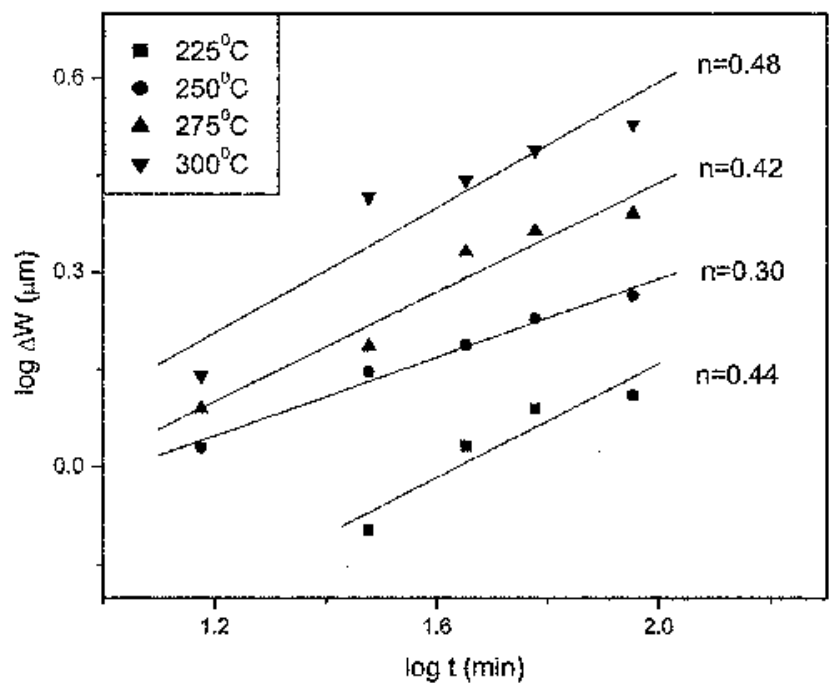

Fig. 12. Log plot for the thickness $(\Delta \mathrm{W})$ of the intermetallic slabs formed during the interfacial reactions between Sn-20ln-2.8Ag solder and $\mathrm{Ni}$ substrates at various temperatures.

reactions at various temperatures. At lower temperatures $\left(225-275^{\circ} \mathrm{C}\right)$, a homogeneous layer of intermetallic compounds is formed, accompanied by the presence of a certain number of elongated grains at its front. In this temperature range, the rate-controlling step in intermetallic growth is the lattice diffusion of $\mathrm{Ni}$ atoms through the dense intermetallic layer, thereby establishing a parabolic kinetic relation between intermetallic growth length $(\Delta \mathrm{X})$ and reaction time (t). The activation energy for this type of intermetallic growth is about $25.4 \mathrm{KJ} / \mathrm{mol}$, which is quite consistent with the activation energy reported by Yeh and Huntington ${ }^{16}$ for the lattice diffusion of $\mathrm{Ni}$ in $\mathrm{Sn}(18.1 \mathrm{KJ} / \mathrm{mol})$. The interfacial intermetallic compounds formed during the soldering reactions at higher temperatures $\left(300-350^{\circ} \mathrm{C}\right)$ appear in long needle shapes. The grooves between the intermetallic needles provide fast-diffusion paths for $\mathrm{Ni}$ atoms to react with $\mathrm{Sn}$ atoms at the intermetallic front. In this case, the intermetallic growth kinetics is governed by a linear relation, signifying an interfacecontrolled mechanism. After selective etching away of the unreacted solder, the exposed interfacial intermetallic compounds appear in the shape of elongated flat slabs. Through such a three-dimensional morphology, a transverse growth of intermetallic slabs accompanied with the lengthening of the slabs in the longitudinal direction can be identified. Kinetic analysis reveals that such a transverse coarsening phenomenon of $\mathrm{Ni}_{3}\left(\operatorname{In}_{0.99} \operatorname{In}_{0.01}\right)_{4}$ intermetallics at 
the $\mathrm{Sn}-20 \mathrm{In}-2.8 \mathrm{Ag} / \mathrm{Ni}$ interfaces is governed by the Ostwald ripening mechanism.

\section{ACKNOWLEDGEMENT}

The authors sincerely thank the National Science Council, Taiwan, for the sponsorship of this research under Grant No. NSC-91-2216-E002-036.

\section{REFERENCES}

1. S. Kang and A. Sarkhel, J. Electron. Mater. 23, 701 (1994).

2. W.J. Tomlinson and A. Fullylove, J. Mater. Sci. 27, 5777 (1992).

3. W.K. Choi and H.M. Lee, J. Electron. Mater. 29, 1207 (2000).

4. Z. Mei and J.W. Morris, J. Electron. Mater. 21, 401 (1992).

5. Z. Mei and J.W. Morris, J. Electron. Mater. 21, 599 (1992).

6. D.M. Jacobson and D. Humpston, Gold Ball. 22, 9 (1989).

7. S.K. Kang and V. Ramachandran, Scripta Metall. 14, 421 (1980).
8. M.Y. Chiu, S.Y. Chang, Y.H. Tseng, Y.C. Chang, and T.H. Chung, Z. Metallkd. 93, 248 (2002).

9. S. Bader, W. Gust, and H. Hieber, Acta Metall. Mater. 43, 329 (1995).

10. Y.H. Tseng and M.S. Yeh, J. Electron. Mater. 28, 105 (1999).

11. Y.H. Tseng (Ph.D. Thesis, National Taiwan University, 2000).

12. Y.C. Chan, M.Y. Chiu, and T.H. Chuang, Z. Metallkd. 93, 95 (2002).

13. C.Y. Huang and S.W. Chen, J. Electron. Mater. 31, 152 (2002).

14. P.G. Kim, J.W. Jang, T.Y. Lee, and K.N. Tu, J. Appl. Phys. 86, 6746 (1999).

15. T.H. Chuang, H.M. Wu, M.D. Cheng, S.Y. Chang, and S.F. Yen, J. Electron. Mater. 33, 22 (2004).

16. D.C. Yeh and H.B. Huntington, Phys. Rev. Lett. 53, 1469 (1984).

17. H.K. Kim, H.K. Liou, and K.N. Tu, Appl. Phys. Lett. 66, 2337 (1995).

18. H.K. Kim and K.N. Tu, Phys. Rev. B 53, 16027 (1996). 